\title{
IL1B wt Allele
}

National Cancer Institute

\section{Source}

National Cancer Institute. IL1B wt Allele. NCI Thesaurus. Code C50929.

Human IL1B wild-type allele is located within 2q14 and is approximately $7 \mathrm{~kb}$ in length.

This allele, which encodes interleukin-1 beta protein, plays a major role in the mediation of inflammatory responses. IL1B is also involved in various other cellular processes such as proliferation, differentiation and apoptosis. 